\title{
Hydromorphological quality as a key element of the ecological status of Polish Carpathian rivers
}

\author{
Bartłomiej WYŻGA ${ }^{1 *}$ and Joanna ZAWIEJSKA ${ }^{2}$ \\ ${ }^{1}$ Institute of Nature Conservation, Polish Academy of Sciences, Kraków \\ 2 Institute of Geography, Pedagogical University of Cracow \\ * Correspondence to: Bartłomiej Wyżga, Institute of Nature Conservation, Polish Academy of Sciences, Kraków, Poland. \\ E-mail: wyzga@iop.krakow.pl
}

(C)2012 University of Suceava and GeoConcept. All rights reserved

doi: 10.4316/GEOREVIEW.2012.21.1.55

\section{Article history}

Received: October 2012

Received in revised form:

November 2012

Accepted: December 2012 Available online: January 2013
ABSTRACT: After a few decades of efforts to detect, quantify and counteract the effects of water pollution on river biota, recent years have brought an increasing understanding of the significance of hydromorphological quality of rivers for their ecological status, and research on Polish Carpathian rivers has contributed to the progress in this field. Our team developed a method of hydromorphological assessment of rivers, which is based on the European Standard EN-14614 and compromises between the needs for practical application and the environmental significance of results. Application of the method in rivers with different channel patterns confirmed its usefulness and showed a significant impact of channelization and channel incision on the hydromorphological quality of Carpathian rivers. Both disturbances simplified flow pattern and homogenised physical habitat conditions in rivers, and the changes are clearly reflected in the reduced abundance and diversity of fish fauna as well as the reduced taxonomic diversity of benthic invertebrate communities. Significant relationships between these biotic characteristics of Polish Carpathian rivers on one hand and the variation of physical habitat conditions and hydromorphological quality of the rivers on the other indicate that recovery of the degraded communities requires such restoration measures that will increase morphological complexity of the watercourses. Environmental changes that took place in Carpathian catchments during the twentieth century have changed water and sediment fluxes in the rivers and thus make it impossible to use the historical state of the watercourses as reference for their restoration. Therefore, reference conditions should be defined as those which exist or would exist under present environmental conditions in the catchment but with the lacking human influence on the channel, riparian zone and floodplain of the river which is to be restored. An erodible corridor seems to be a restoration measure enabling the most effective adjustment of a degraded river to its contemporary regime as well as re-establishment of geomorphic dynamic equilibrium conditions and improvement of hydromorphological conditions for river biota.

KEY WORDS: mountain river, hydromorphological quality, reference conditions, ecological status 


\section{Introduction}

During recent historical times, various pressures related to human activities in catchments and river valleys have resulted in substantial impact on mountain watercourses, with harmful effects on the condition of their ecosystems. Degradation of water quality resulting from increasing delivery of biogenic and chemical pollutants was first recognised as an important cause of declining ecological integrity of river ecosystems. This has stimulated substantial efforts to detect, quantify and counteract the effects of water pollution on river biota, and currently water quality in many mountain rivers in densely populated areas is better than it was still a few decades ago. Recognition of detrimental effects of the degradation of physical habitats in rivers took place only after the mid-1990s, despite the ubiquitous occurrence of such disturbances as river channelization, in-channel sediment mining, flow regulation and disruption of river continuity by dams and weirs.

With the increasing understanding of the significance of the physical habitat integrity of rivers for their ecological status, the EC Water Framework Directive (European Commission, 2000) introduced the term 'hydromorphology' to describe physical habitat conditions for aquatic biota as they are determined by the hydrological regime and morphological pattern (Rinaldi et al., 2013). Spatial complexity of habitats, connectivity and dynamism were indicated as key attributes of hydromorphological quality of rivers (Elosegi et al., 2010). After a few decades of concern about the water quality of watercourses, identification of major stressors for river ecosystems now focuses on modifications of river morphology and flow regime and the impact of artificial barriers on biota migration, water flow and sediment transport (Vaughan et al., 2009).

A number of aspects concerning the relations between the condition of biotic components of river ecosystems and physical habitat integrity need to be recognised to enable identification of the causes of degradation of the ecological status of particular rivers and formulate appropriate restoration measures (Vaughan et al., 2009; Rinaldi et al., 2013), and research on Polish Carpathian rivers has contributed to the progress in this field. This paper focuses on:

development of a practical and environmentally significant method of hydromorphological assessment of rivers

the impact of human disturbances on hydromorphological quality of Carpathian rivers and their reflection in the condition of river biocoenoses

- the mode of defining hydromorphological reference conditions for river restoration

- identification and implementation of restoration measures highly effective in improving the hydromorphological integrity of piedmont and mountain rivers.

\section{Hydromorphological assessment of rivers}

Since the late 1990s a number of methods of hydromorphological quality assessment have been developed in Europe. Most of these methods require field-based evaluation of a large number of physical habitat features (e.g. River Habitat Survey in the UK) and neglect processes and channel 
adjustment trends. Procedures of river habitat survey assume that hydromorphological status of a river is a function of the abundance and diversity of habitat features beneficial for riverine biota. This assumption is really problematic as many unmodified river reaches may naturally exhibit relatively simple morphological conditions and, hence, little abundance and diversity of habitat features.

On the opposite side there is the recently published European Standard EN-15843 (CEN, 2010) providing methodology for map-based assessments of the river state which are fast but of little use for the practice of river restoration. The main deficiency of this methodology is the use of a simple dichotomy: modified/unmodified and evaluating particular river features based on the proportion of reach length where a given feature has been modified by man, without considering the degree of this modification.

As both these approaches have apparent deficiencies, our team has developed a method based on the European Standard EN-14614 (CEN, 2004), which compromises between the needs for practical application and the environmental significance of the results (Wyżga et al., 2009, 2010, 2012a). In the method, hydromorphological river quality is assessed through scoring of 10 groups of features of the channel, banks, riparian zone and floodplain of a river, according to their specification in the European Standard EN-14614 (CEN, 2004; see also Table 1 in Wyżga et al., 2009). The assessment should be made simultaneously by specialists in fluvial geomorphology, hydrobiology and river engineering/water management. Each assessed feature is scored on the scale from 1 for near-natural conditions to 5 for extremely modified conditions. Based on the aggregated score for 10 assessed categories, averaged from the scores of particular experts, each evaluated object (cross-section, river reach) is subsequently associated with a particular class of hydromorphological river quality.

The assessment is preceded by field inspection of the evaluated river and presentation of three types of data. First, for each evaluated feature, its near-natural and extremely modified states are presented (as it is shown in Fig. 1 for the presence of erosional and depositional channel forms), whereas the whole spectrum of possible conditions between these extreme states is left for expert evaluation. Second, the contemporary river state is indicated by presentation of crossprofiles of the river and river appearance on ground photos and orthophotos. Third, changes of the river over the past few decades are analysed with use of cartographic and photographic documents. The presented method of hydromorphological assessment (Wyżga et al., 2010, 2012a) thus utilizes information derived from field inspection, contemporary river images and aerial photos/maps from the past decades. The last source of information does not provide historical reference conditions but is intended to place contemporary physical river features in the context of ongoing processes and trends of river adjustment.

\section{Changes of the hydromorphological quality of mountain rivers and their reflection in the condition of river biocoenoses}

During the 20th century rivers draining the Polish Carpathians were considerably modified by human disturbances. Widespread channelization works (e.g. Zawiejska, Wyżga, 2010) and inchannel gravel mining (Rinaldi et al., 2005) have induced rapid channel incision (Wyżga, 2008); moreover, several dam reservoirs and a large number of weirs were constructed. Changes to physical habitat complexity and hydromorphological river quality resulting from these impacts 
were studied in a few Polish Carpathian rivers.

Studies on the Czarny Dunajec indicated that the cross-sections with four low-flow channels exhibit significantly greater variability in flow depth, velocity and bed-material grain size than single-thread cross-sections (Wyżga et al., 2009) and that the degree of variability in these physical habitat parameters increases with increasing complexity of flow pattern (Wyżga et al., 2011). Similarly, a study on the Biała demonstrated clear differences in the degree of variability of physical habitat parameters between unmanaged river cross-sections with an average of two low-flow channels and single-thread, channelized cross-sections (Wyżga et al., in press).

Hydromorphological assessment of the Czarny Dunajec indicated that considerable variability in the degree of human impact along the river is reflected in highly varied hydromorphological quality of the evaluated cross-sections. Unmanaged, multi-thread cross-sections were classified as representing high-status conditions, unmanaged cross-sections with deeply incised channel were considered to represent Class 2 and single-thread cross-sections Class 4 of hydromorphological river quality (Wyżga et al., 2009, 2010).

In turn, the assessment of 10 channelized and 10 unmanaged cross-sections of the Biała River documented significant differences between the two types of river cross-sections in every evaluated category. Average scores indicated that unmanaged cross-sections on that river represent Class 2 and channelized cross-sections Class 3 of hydromorphological quality (Table 1) (Wyżga et al., 2012a).

Significant relations were identified between biotic components of the ecosystems of Carpathian rivers and their hydromorphological characteristics. The abundance and diversity of fish fauna in the Czarny Dunajec were shown to increase linearly with increasing cross-sectional variation of flow depth and the number of low-flow channels in a cross-section and exponentially with improving hydromorphological river quality (Wyżga et al., 2009). Especially large increase in the number of both juvenile (Fig. 2) and adult fish individuals occurred with relatively small improvement from good to high hydromorphological quality of the river that was associated with the change from its island-braided to heavily island-braided morphology.

The study on benthic invertebrate communities in the Czarny Dunajec (Wyżga et al., 2011, $2012 \mathrm{~b}$ ) indicated that taxonomic richness of this group of river biota increases with increasing cross-sectional variation of flow depth, depth-averaged and near-bed velocity and bed-material grain size (Table 2). Notably, the greatest portion of the total variation in the number of invertebrate taxa was explained by the number of low-flow channels in a cross-section (Table 2). Increased complexity of the flow pattern is associated with greater lateral variability in many environmental parameters, not only those measured in the study but also others, such as water temperature, retention of wood debris or fine organic matter, which altogether determine the heterogeneity of riverine habitats, beneficial for a variety of invertebrate taxa (Wyżga et al., 2011, 2012b). 

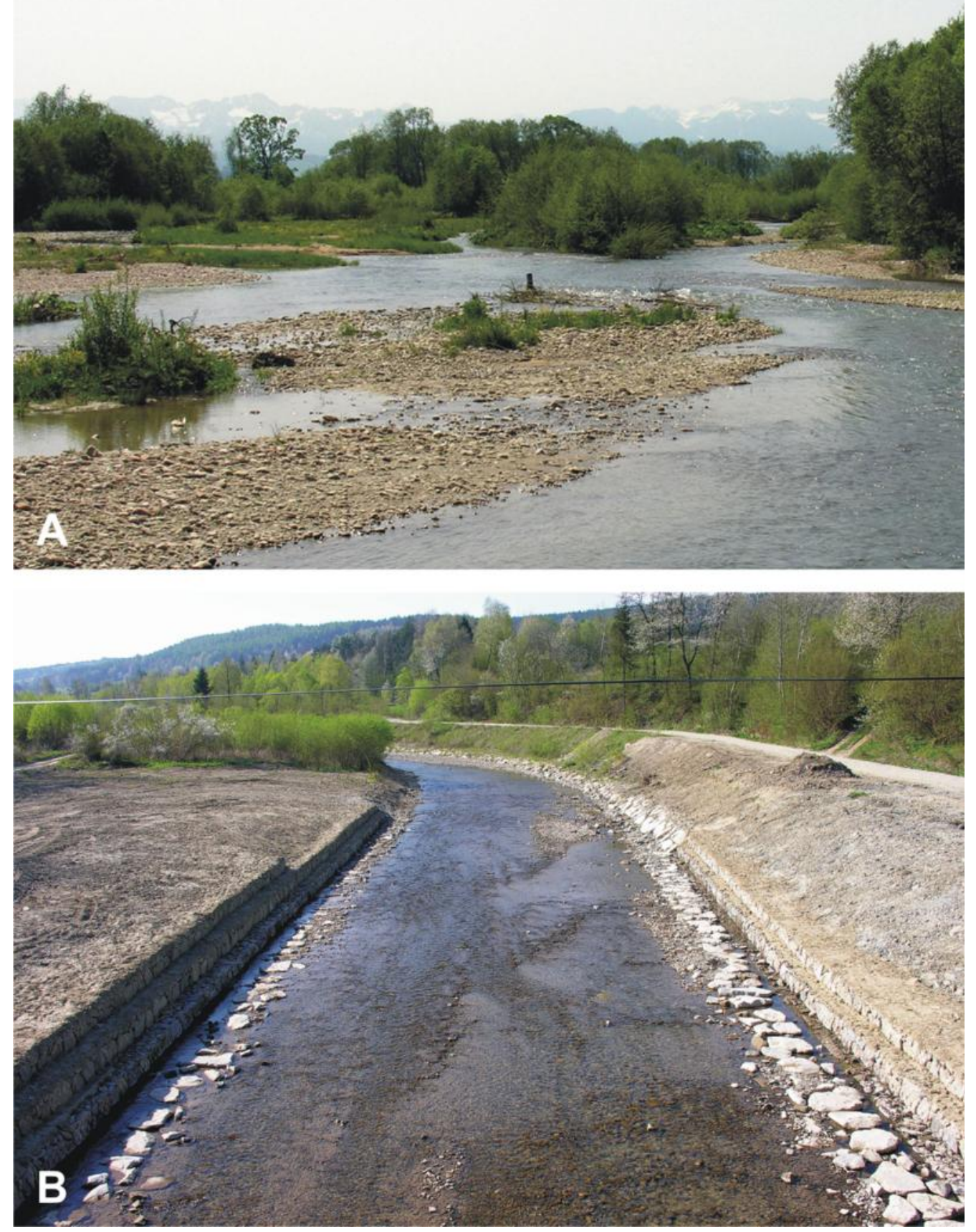

Figure 1. Examples of near-natural (A) and extremely modified conditions (B) for the presence of erosional and depositional channel forms in a gravel-bed mountain river. Under near-natural conditions, depositional forms are represented by gravel bars and vegetated islands. Extremely modified conditions are associated with a lack of cross-sectional and longitudinal differentiation of the channel bed into erosional and depositional forms. This figure is available in colour online at www.georeview.ro 
Table 1. Mean scores given in particular assessment categories to unmanaged and channelized crosssections of the Biała River and the results of a Wilcoxon test for the significance of difference of mean scores between both cross-section types

\begin{tabular}{lccc}
\hline Assessment category & $\begin{array}{c}\text { Mean score for } \\
\text { unmanaged } \\
\text { cross-sections }\end{array}$ & $\begin{array}{c}\text { Mean score for } \\
\text { channelized } \\
\text { cross-sections }\end{array}$ & $\begin{array}{c}\text { p value of } \\
\text { Wilcoxon test }\end{array}$ \\
\hline Channel geometry & 2.22 & 4.05 & $\mathrm{p}=0.005$ \\
Substrate & 1.54 & 2.18 & $\mathrm{p}=0.015$ \\
In-river vegetation and organic debris & 3.01 & 3.69 & $\mathrm{p}=0.008$ \\
Erosion/deposition character & 1.68 & 3.30 & $\mathrm{p}=0.005$ \\
Flow & 1.73 & 2.63 & $\mathrm{p}=0.005$ \\
Longitudinal river continuity & 1.04 & 1.64 & $\mathrm{p}=0.02$ \\
Bank structure & 1.44 & 3.43 & $\mathrm{p}=0.005$ \\
Vegetation/land use in riparian zone & 1.69 & 3.05 & $\mathrm{p}=0.005$ \\
Land use in the river corridor & 2.44 & 3.45 & $\mathrm{p}=0.009$ \\
Lateral connectivity/channel migration & 1.68 & 4.41 & $\mathrm{p}=0.005$ \\
\hline Average score & $\mathbf{1 . 8 5}$ & $\mathbf{3 . 1 8}$ & $\mathbf{p}=\mathbf{0 . 0 0 5}$ \\
\hline
\end{tabular}

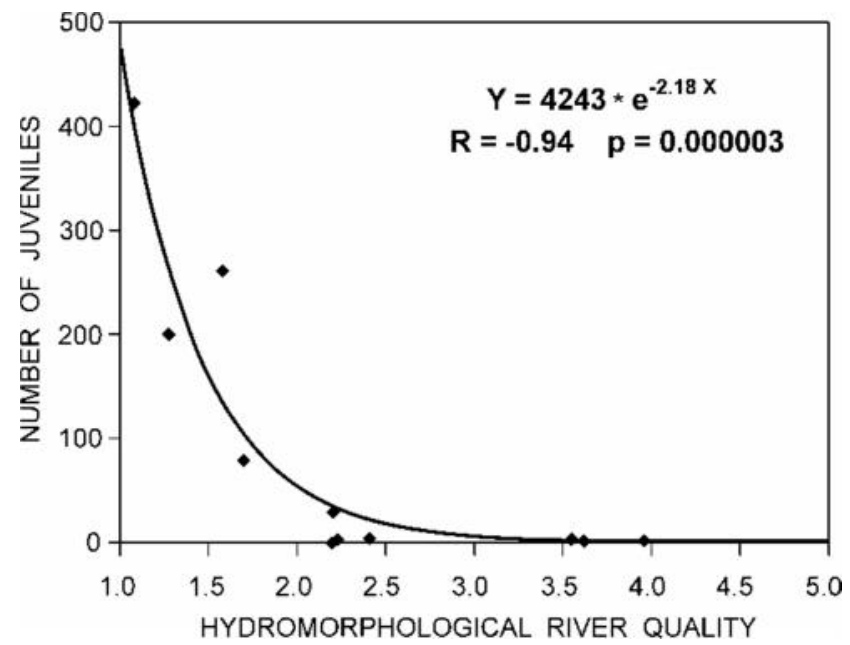

Figure 2. Scatter plot and estimated regression relationship between the number of fish juveniles caught in the investigated cross-sections of the Czarny Dunajec and hydromorphological river quality in the cross-sections.

An interesting outcome of the studies on benthic invertebrate communities in the Czarny Dunajec and the Biała was a lack of dependence of the taxonomic richness of invertebrates on water quality in the rivers. Instead, differences in the taxonomic richness reflected varied hydromorphological complexity of the studied cross-sections. While these results do not negate water pollution as an important stressor limiting the diversity of benthic invertebrate communities in mountain rivers, they do emphasize a significant role of physical habitat heterogeneity in controlling the taxonomic richness of the communities (Wyżga, 2012b, in press). 
Table 2. Explanation and significance of linear regression models estimated between the number of benthic invertebrate taxa recorded in the investigated cross-sections of the Czarny Dunajec River and selected physical habitat characteristics of the cross-sections

\begin{tabular}{lccc}
\hline Independent variable & Beta value & $\begin{array}{c}\text { Goodness- } \\
\text { of-fit }\end{array}$ & Significance \\
\hline Coefficient of variation of flow depth & $B=0.66$ & $R^{2}=0.44$ & $p=0.003$ \\
Coefficient of variation of depth-averaged velocity & $B=0.51$ & $R^{2}=0.26$ & $p=0.03$ \\
Coefficient of variation of near-bed velocity & $B=0.49$ & $R^{2}=0.24$ & $p=0.04$ \\
Coefficient of variation of bed-material grain size & $B=0.58$ & $R^{2}=0.34$ & $p=0.01$ \\
\hline Number of low-flow channels & $\mathbf{B}=\mathbf{0 . 8 4}$ & $\mathbf{R}^{\mathbf{2}}=\mathbf{0 . 7 1}$ & $\mathbf{p}=\mathbf{0 . 0 0 0 0 1}$ \\
\hline
\end{tabular}

\section{Defining hydromorphological reference conditions for river restoration}

With now widely recognised need for improvement of the ecological status of degraded river ecosystems, restoration actions are likely to be undertaken on many river systems. Despite a general agreement that river restoration should be based on pre-defined reference conditions, no common approach to the identification of reference river state exists and various concepts are applied in particular countries or by particular scientists. Wyżga et al. (2012c) discussed usefulness of the most common concepts of hydromorphological reference conditions, concluding that all of them have serious deficiencies. Here we focus on the suitability of a historical state of Polish Carpathian rivers as reference for their restoration. Cartographically documented historical state of rivers is a common concept of reference conditions, benefiting from the fact that good cartographical record of channel patterns is available for the 19th century throughout Europe. However, in Europe, the 19th century was the time of the highest pastoral and agricultural pressures on river catchments, especially in montane regions. With their flashy runoff and high sediment flux, rivers of that time neither represent natural conditions nor can be restored nowadays when such activities in the catchments have greatly declined (Wyżga et al., 2012c).

During the 20th century considerable land use changes took place in the Polish Carpathian catchments, leading to a remarkable reduction in the percentage of arable land and an increase in forest cover. For instance, in the upper Dunajec River catchment, the proportion of arable land decreased over the century from $42 \%$ to $17.5 \%$, whereas the forest cover increased from $27 \%$ to $42 \%$ (Wyżga et al., 2012c). Moreover, in the second half of the century a reduction in flood flows generated by the Carpathian catchments occurred, mostly reflecting changes in precipitation pattern (Wyżga, 2008; Zawiejska, Wyżga, 2010; Wyżga et al., 2012c). Reduced flow and sediment dynamics resulting from these environmental changes have induced adjustments to river morphology. In the rivers supplied with coarse material and forming non-cohesive alluvial plains, such as the Czarny Dunajec, multi-thread morphology was retained in unmanaged sections but channel pattern changed from bar-braided to island-braided. The rivers fed with finer-grained material delivered from flysch catchments, especially those with a large proportion of shale lithology, changed their former multi-thread channel pattern to single-thread pattern; at the same time, a tendency to meander appeared in their unmanaged sections (Wyżga et al., 2012c). These morphological adjustments, apparent in unmanaged river sections, indicate that environmental changes in the catchments and the resultant alterations to water and sediment 
fluxes in the rivers make it impossible to restore human-modified river sections to their 19thcentury morphology. Therefore, we indicate that reference conditions should be defined as those which exist or would exist under present environmental conditions in the catchment but without human influence on the channel, riparian zone and floodplain of the river which is to be restored (Wyżga et al., 2012c). Substantial climate changes projected over the 21st century highlight the significance of such understanding of reference conditions. As climate changes progress, they will induce channel adjustments and cause latitudinal and altitudinal shifts in the density and composition of riparian vegetation, changes to water temperature, river regime and the persistence of run-off (Rinaldi et al., 2013). All these changes will inevitably result in significant changes to river habitats and biocoenoses.

\section{Erodible river corridor as an effective measure to improve hydromorphological integrity of piedmont and mountain rivers}

Restoration actions undertaken on hydromorphologically degraded rivers should allow: (i) improvement of physical habitat conditions for riverine and riparian biota to enhance the ecological integrity of the rivers; and (ii) re-establishment of an undisturbed course of fluvial processes and the conditions of geomorphic dynamic equilibrium wherever it is possible without threats to settlements and infrastructure on the valley floors (Wyżga et al., 2012c).

So far, restoration projects have been mostly focused on improving habitat conditions for a given group of riverine biota, especially fish, or even for a single fish species, and restoring more nature-like river form rather than river processes that would make such river form selfsustaining. A restoration measure fulfilling the above indicated requirements is an erodible river corridor within which free migration of the river channel is allowed (Piégay et al., 2005; Bojarski et al., 2005). Delimitation of an erodible river corridor is associated with resigning from construction/maintenance of bank-protection structures. Instead, boundaries between the erodible corridor and managed parts of the valley floor are enforced to avoid erosion (Fig. 3).

The active channel migration within an erodible corridor is intended (cf. Bojarski et al., 2005; Nieznański et al., 2008):

$\square$ to increase retention of flood water in the reach through the continual formation of lowlying floodplain areas

to increase morphological and hydraulic complexity of the river, necessary to maintain/restore a high diversity of riverine habitats

to enable the formation of early successional stages of riparian vegetation, which does not occur if the channel is artificially stabilised

to reduce transport capacity of the river due to an increase in channel-form resistance to flow associated with the formation of natural channel.

Moreover, a reduction of the costs of river maintenance in the reach can be expected as revetments on the corridor boundaries will be less often subjected to erosion than bankprotection structures normally would.

Even though many mountain and piedmont sections of the rivers of southern Poland have been constricted by settlements and infrastructure, numerous sections still exist with enough room for free channel migration on the valley floors (Fig. 4). To date, erodible corridors have been implemented on three rivers of southern Poland. In 2005 such a corridor was delimited in a $7 \mathrm{~km}$ long, meandering reach of the upper Oder at the Czech-Polish border (Nieznański et al., 2008). In 
a few past years, erodible corridor was also established in two sections located in mountain and foothill courses of the Biała River, with a total length of about $17 \mathrm{~km}$, and in a $3 \mathrm{~km}$-long section of the upper Raba River (Fig. 4).

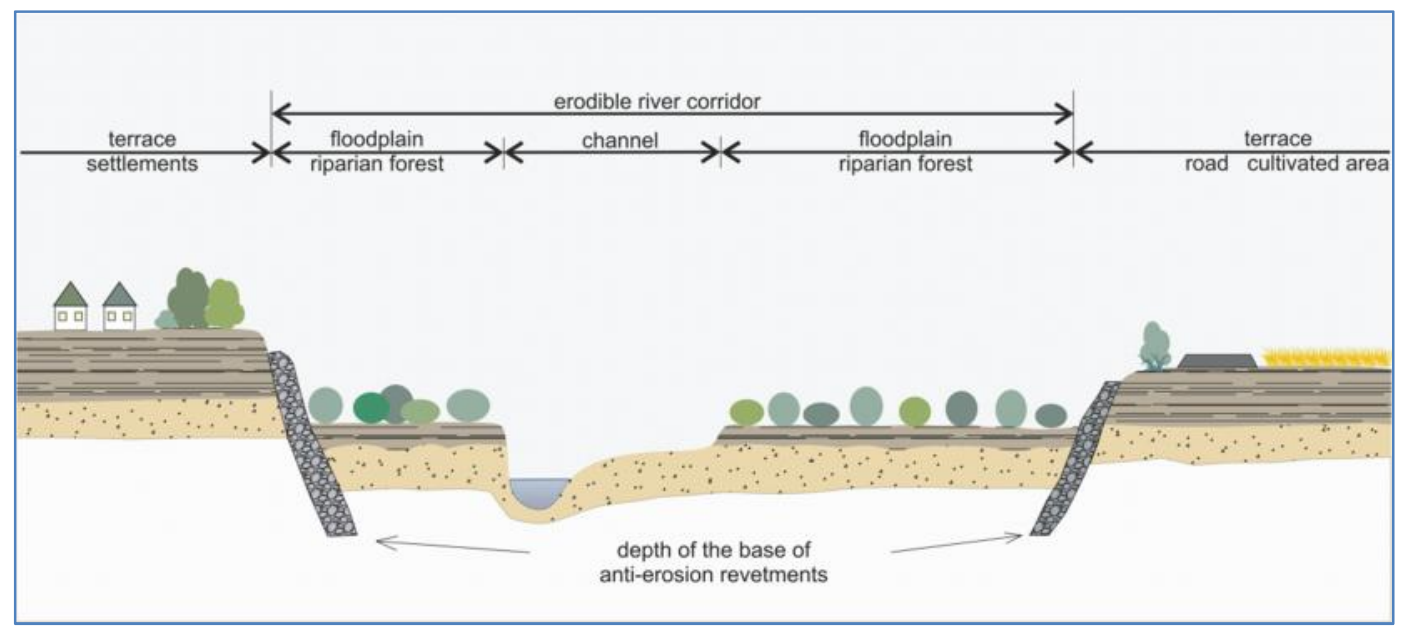

Figure 3. The concept of erodible river corridor, with free channel migration possible within the floodplain area and channel bank reinforcements replaced by anti-erosion revetments constructed on the boundary between river floodplain and managed terrace (after Bojarski et al., 2005). This figure is available in colour online at www.georeview.ro

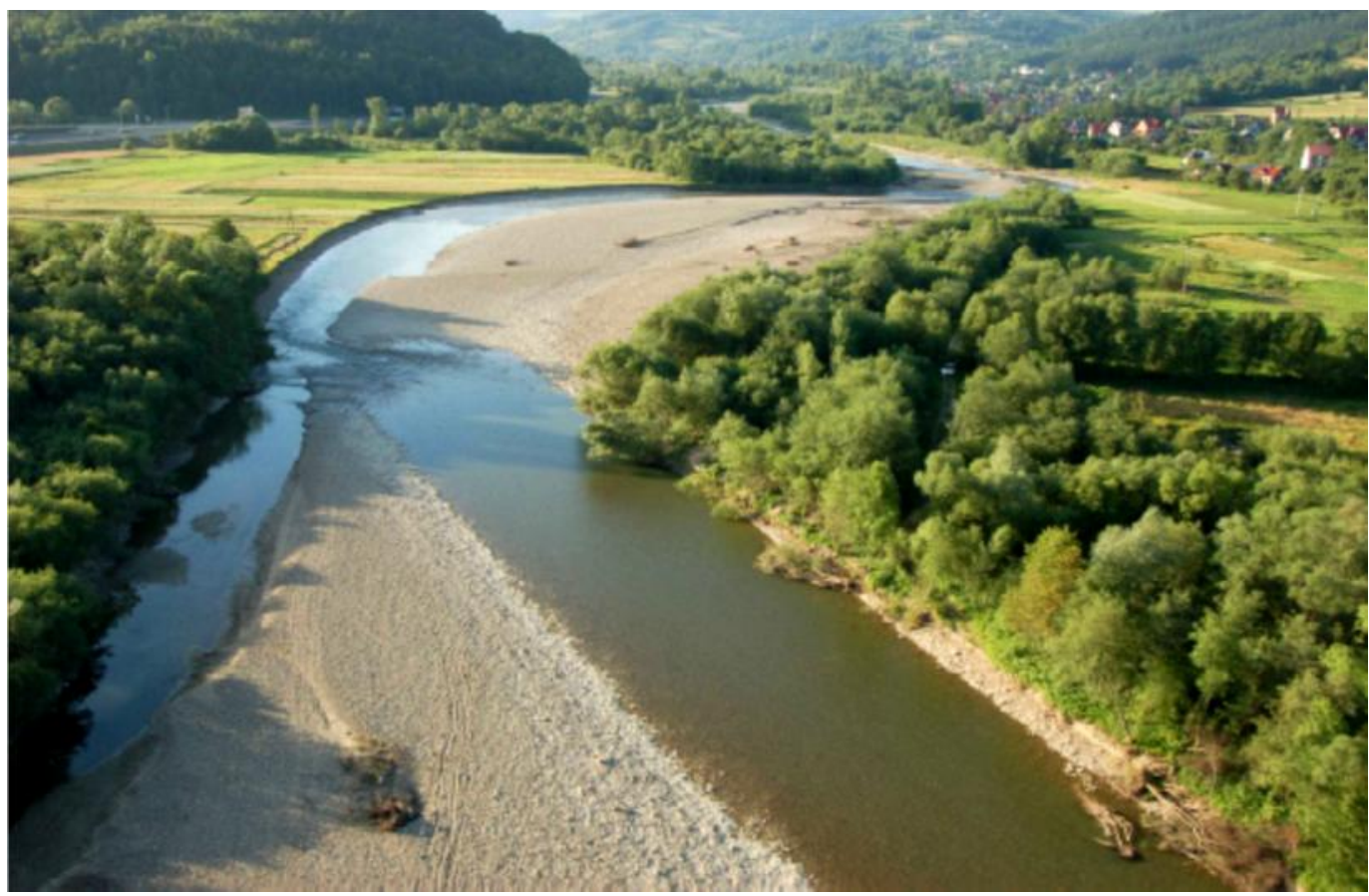

Figure 4. Oblique aerial photo of the Raba channel within the erodible corridor delimited in the vicinity of Lubień village. A relatively wide span between settlements and roads on both river sides provides the room for free channel migration and makes bank reinforcements unnecessary in this river reach. Photo by Łukasz Ślusarski, published by courtesy of Ab Ovo Association. This figure is available in colour online at www.georeview.ro 
Successful functioning of an erodible corridor requires public ownership of the riparian land in order to avoid the demand of stabilising the channel and protecting the banks from erosion. The purchase of riparian areas from private landowners was an integral part of the restoration projects on the Oder (Nieznański et al., 2008) and the Biała, whereas on the Raba most of the riparian land within the delimited erodible corridor is already owned by the state.

\section{Conclusions}

Hydromorphological evaluation conducted with the proposed method (Wyżga et al., 2010) requires professional knowledge and gathering specialists in various disciplines. As a consequence, the method gives reliable and environmentally meaningful results and indicates precisely which features of the river ecosystem require improvement at a given location, hence providing a basis for informed decisions about river restoration. However, it is not useful for generating simplified reports on the river integrity on a national/basin scale.

Studies on Polish Carpathian rivers indicate that channel regulation, gravel mining-induced channel incision and construction of dams and weirs resulted in considerable simplification of physical habitat pattern and degradation of the hydromorphological quality of the rivers. These changes to the physical structure of the river ecosystems are clearly reflected in the impoverishment of fish and benthic invertebrate communities. This indicates that recovery of these communities will require an increase in morphological complexity of the rivers.

With their flashy runoff and high sediment flux, 19th-century rivers neither represent natural conditions nor can be restored nowadays when agricultural and pastoral activities in the catchments have greatly declined. This invalidates a historical state of Polish Carpathian rivers as reference for their restoration. Instead, defining hydromorphological reference conditions should be based on the conditions actually or potentially existing under present environmental conditions in the catchment and associated with a lack of human influence on the channel, riparian zone and floodplain of a river.

An erodible corridor is a restoration measure enabling an effective adjustment of a degraded river to its contemporary regime and improvement of a variety of river characteristics, including re-establishment of geomorphic dynamic equilibrium conditions, an increase of the potential for flood water storage in the floodplain area and improvement of hydromorphological conditions for riverine and riparian biota. First restoration projects aiming at establishing erodible corridors on Polish Carpathian rivers have been started in recent years.

\section{Acknowledgements}

This study was performed within the scope of the Research Project N N305 097239 financed by the Polish Ministry of Science and Higher Education. 


\section{References}

Bojarski A., Jeleński J., Jelonek M., Litewka T., Wyżga B., Zalewski J. 2005. Zasady dobrej praktyki w utrzymaniu rzek i potoków górskich (Good-Practice Manual on Sustainable Maintenance of Mountain Streams and Rivers in Southern Poland). Ministerstwo Środowiska, Warszawa (in Polish, with English summary).

CEN 2004. Water Quality - Guidance Standard for Assessing the Hydromorphological Features of Rivers. EN-14614. CEN, Brussels.

CEN 2010. Water Quality - Guidance Standard on Determining the Degree of Modification of River Hydromorphology. EN-15843. CEN, Brussels.

Elosegi A., Díez J., Mutz M. 2010. Effects of hydromorphological integrity on biodiversity and functioning of river ecosystems. Hydrobiologia, 657: 199-215.

European Commission. 2000. Directive 2000/60 EC of the European Parliament and of the Council of 23 October 2000 Establishing a Framework for Community Action in the Field of Water Policy. Official Journal of the European Communities, L 327(43): 1-72.

Nieznański P., Wyżga B., Obrdlik P. 2008. Oder border meanders: A concept of the erodible river corridor and its implementation. In: Gumiero B., Rinaldi M., Fokkens B. (Eds), 4th ECRR International Conference on River Restoration, ECRR, Venice, pp. 479-486.

Piégay H., Darby S., Mosselman E., Surian N. 2005. A review of techniques available for delimiting the erodible river corridor: a sustainable approach to managing bank erosion. River Research and Applications, 21: 773-789.

Rinaldi M., Wyżga B., Dufour S., Bertoldi W., Gurnell A. 2013. River processes and implications for fluvial ecogeomorphology: An European perspective. In: Shroder J., Butler D., Hupp C.R. (Eds), Treatise on Geomorphology. Volume 12. Ecogeomorphology, Academic Press, San Diego, pp. 37-52.

Rinaldi M., Wyżga B., Surian N. 2005. Sediment mining in alluvial channels: physical effects and management perspectives. River Research and Applications, 21: 805-828.

Vaughan I.P., Diamond M., Gurnell A.M., Hall K.A., Jenkins A., Milner N.J., Naylor L.A., Sear D.A., Woodward G., Ormerod S.J. 2009. Integrating ecology with hydromorphology: a priority for river science and management. Aquatic Conservation: Marine and Freshwater Ecosystems, 19: 113-125.

Wyżga B. 2008. A review on channel incision in the Polish Carpathian rivers during the 20th century. In: Habersack H., Piégay H., Rinaldi M. (Eds), Gravel-bed Rivers VI: From Process Understanding to River Restoration. Elsevier, Amsterdam, pp. 525-555.

Wyżga B., Amirowicz A., Radecki-Pawlik A., Zawiejska J. 2009. Hydromorphological conditions, potential fish habitats and the fish community in a mountain river subjected to variable human impacts, the Czarny Dunajec, Polish Carpathians. River Research and Applications, 30: 517-536.

Wyżga B., Zawiejska J., Radecki-Pawlik A., Amirowicz A. 2010. A method for the assessment of hydromorphological river quality and its application to the Czarny Dunajec, Polish Carpathians. In: Radecki-Pawlik A., Hernik J. (Eds), Cultural Landscapes of River Valleys, Agricultural University in Kraków, Kraków, pp. 145-164. 
Wyżga B., Oglęcki P., Radecki-Pawlik A., Zawiejska J. 2011. Diversity of macroinvertebrate communities as a reflection of habitat heterogeneity in a mountain river subjected to variable human impacts. In: Simon A., Bennett S.J., Castro J.M., Thorne C. (Eds), Stream Restoration in Dynamic Systems: Scientific Approaches, Analyses and Tools. American Geophysical Union, Washington, pp. 189-207.

Wyżga B., Hajdukiewicz H., Zawiejska J., Amirowicz A., Oglęcki P., Radecki-Pawlik A. $2012 a$. Practical and environmentally significant method of hydromorphological assessment of rivers. International Conference 'Integrative sciences for sustainable development of rivers', July 2012, Lyon, France, 161: 1-3.

Wyżga B., Oglęcki P., Radecki-Pawlik A., Skalski T., Zawiejska J. 2012b. Hydromorphological complexity as a driver of the diversity of benthic invertebrate communities in the Czarny Dunajec River, Polish Carpathians. Hydrobiologia, 696: 29-46.

Wyżga B., Zawiejska J., Radecki-Pawlik A., Hajdukiewicz H. 2012c. Environmental change, hydromorphological reference conditions and the restoration of Polish Carpathian rivers. Earth Surface Processes and Landforms, 37: 1213-1226.

Wyżga B., Oglęcki P., Hajdukiewicz H., Zawiejska J., Radecki-Pawlik A., Skalski T., Mikuś P. (in press) Interpretation of the invertebrate-based BMWP-PL index in a gravel-bed river: insight from the Polish Carpathians. Hydrobiologia, DOI 10.1007/s10750-012-1280-0

Zawiejska J., Wyżga B. 2010. Twentieth-century channel change on the Dunajec River, southern Poland: patterns, causes and controls. Geomorphology, 117: 234-246. 